\title{
Newly Selected Soybean Genotypes and Their Resistance Against the Two-Spotted Spider mite Tetranychus urticae Koch
}

\author{
Hala H. Alakhder \\ Plant Protec. Res. Inst.. Agric. Res. Center, Dokki. Giza. Egypt.
}

\begin{abstract}
The effect of some factors on the susceptibility of eleven soybean genotypes against Tetranychus urticae infestation during two successive seasons 2012 and 2013 was evaluated. The highest population density, in terms of motile and egg stages, was recorded on the genotype H15L27 (4980.3 and 3670) and (2898 and 2248); while the lowest was for the genotype H191.96 (2146 and 1533.3) and (1573.3 and 1309). respectively for the two years. The lowest infested genotypes were characterized by thickness of the upper and lower epidermis (17.67 and $14.28 \mu)$, as well as palisade tissue and the thinness of spongy tissues $(90.53$ and $51.86 \mu)$. respectively. Mite population density was positively correlated with leaves nitrogen and potassium contents; while negatively correlated with phosphrous. The predatorys, Phytoseiulus persimilis and the thrips, Scolothrips sexmaculatus, populations were recorded the lowest density of T. urricae and vice versa. The susceptibility of soybean genotypes to the spider mite infestation was governed by leaf phytochemical components and histological structure of its surfaces and the presence of natural enemies. These results could be involved in breeding programme cultivated to improve future integrated pest management of soybean in Fgypt.
\end{abstract}

Key words: Tetranychus urticae; Soybean genotypes; Suscpitibility; Histological structure; Phytochemical components; Predators.

\section{INTRODUCTION}

Soybean (Glycine max (L.) Merrill) and it's have been a part of traditional food for human population. Its plants are attacked by many pests of spider mite, Tetranychus urticue (Koch), and can threaten yield quality and quantity (Massoud et al., 2014). It feeds using piercing-sucking process that damages plant cells and tissue leading to the appearance of yellow chlorotic spots on leaves (Martinez-Ferrer et al., 2006). Spider mites are difficult to control with pesticides due to inaccessibility of lower leaf surfaces, short life cycle, high reproductive capacity and ability to develop resistance to miticides (Nahar et al., 2005 and Georghiou, 1990). Assessment of susceptibility/resistance of a crop plant towards pests is among the requirements of integrated pest management (IPM). Soybean variety characteristics can affect susceptibility to pest injury. The relation between population of predatory mites, such as Phytoseiulus persimilis Athias Henriot and predatory thrips, six spotted Scolothrips sexmaculatus (Pergande) and their host T.urticae on susceptible and resistant genotypes of soybean was reported to determine the ability of the predators to regulate their prey populations.

Leaves structure has been shown to be related to mite damage or to symptoms commonly associated with damage. The highest density of phytophagus mites occurred on leaves which, in addition to having higher total nitrogen content, had a thicker palisade mesophyll. Some varieties with thicker cuticle and epidermis were more resistant to spider mite. Besides that, the upper leaf surface was less preferred by mites, because its cuticle and epidermis are thicker than that of the lower surface (Kou et al., 1972; Luczynski et al., 1990 and Jyoti et al., 2001).

This study aims to investigate the susceptibility of some soybeans genotypes to the natural infestation of T. urticae under field conditions. Moreover, some factors such as presence of natural enemies, histological structure of leave's surfaces and phytochemical components were investigated.

\section{MATERIALS AND METHODS}

Field experiments were carried out at Gemmiza Research Station, Agric. Res. Center, Gharbia, Egypt during 2012 and 2013 seasons to study the performance of eleven soybean genotypes, including eight newly selected strains (H19L96, L117, H32, H4L24, H15L127, H1L1, L127 and H30) in addition to three commercial varieties (Giza11, Giza35 and Crawford) to $T$. urticae infestation level. These genotypes were obtained from the Field Crops Research Institute, Agricultural Research Center, (Giza / Egypt). The experimental design was a randomized complete block (RCBD) with three replications. Each plot consisted of six ridges, $70 \mathrm{~cm}$ apart and four $\mathrm{m}$. long. Soybean varieties were sown on the $1^{\text {st }}$ week of June. Regular agricultural practices were conducted and plants were irrigated at the same time and no fertilizers or pesticides were provided. (Modarres, 2012).

Population density of spider mite was determined 
of different genotypes from germination until harvest, Jul. 2 to Oct. 4, 2012 and Jul. 4 to Oct. 3, 2013. Leaves were selected randomly from top, middle and lower canopy of each pant. Samples were picked up weekly after 25 days post-plantation. Twenty leaves were randomly collected and transferred to laboratory for examination. Motile stages and eggs of T. urticae, the predatory mite Phytoseiulus persimilis and larvae of the predatory Scolothrips sexmaculatus were counted using stereomicroscope.

Leaf samples of eleven genotypes were collected during the vegetation period, cleaned, washed and dried in an oven at $70{ }^{\circ} \mathrm{C}$ for 48 hours, then grinded into fine powder to determine nitrogen, phosphorous and potassium. Determination of total nitrogen was conducted according to Baker and Thompson (1992). Determination of $\mathrm{P}$ and $\mathrm{K}$ were measured according to Donohue and Aho (1992).

To clarify the relative susceptibility of soybean genotypes to T. urticae infestation in relation to the histological characters of the leaves, leaves from the first fully expanding trifoliate leaves were obtained; cross sections were prepared according to Ruzin (1999). Samples of each variety were placed in the fixed solution FAA, (each $200 \mathrm{ml}$ of FAA composed of $100 \mathrm{ml} 95 \%$ ethanol, $70 \mathrm{ml} \mathrm{dH} 2 \mathrm{O}, 20 \mathrm{ml} 37 \%$ formaldehyde solution and $10 \mathrm{ml}$ glacial acetic acid), four 48 hours then transferred to $70 \%$ alcohol. Transverse sections were made according to Jackson (1976). Different measurements (in micron) of leaf thickness of upper epidermis layer, palisade tissues, spongy tissues and lower epidermal layer were determined.

Population of motile stages infesting different varieties and eggs of T. urticae were counted and statistically analyzed. Simple correlation between pest and its predators, physical and chemical plant leaf properties were calculated, Duncan (1955).

\section{RESULTS AND DISCUSSION}

The accumulated number of $T$. urticae, motile stages (immatures and adults) and eggs on the studied soybean genotypes were estimated during the two successive seasons 2012 and 2013 (Table 1). Statistical analysis indicated significant differences $(\mathrm{P}<0.05)$ between population densities of $T$. urticae on different tested soybean genotypes. The highest number of motile stages was observed on the genotype H15L27 (4980.3 and 2832) followed by H1L1 (4567 and 2600), whereas the lowest numbers were observed on the genotypes H19L96 (2416 and 1573.33) followed by Giza 111 (2738.7 and 1588) for the two seasons 2012 and 2013, respectively.

It is well documented that, plant genotypes differ greatly in suitability as host for a specific pest (Mohamed and Abdel Hafez 1981; Turhan et cl., 1983; Sawires et al., 1990 and Gamieh et al., 2001). The studied genotypes, H15L27, HIL1, L 127 and $\mathrm{H}$ 30 were considered as sensitive soybean genotypes; while H19L96, Giza111, L117, H32, H4L24 and Giza35 had the lowest population densities. In a paralleled study, (Alakhdar et al., 2015) revealed significant differences among the yield of soybean genotypes with respect to $T$. urticae infestation. The genotypes, $\mathrm{H} 19 \mathrm{~L} 96, \mathrm{H} 4 \mathrm{~L} 24$ and $\mathrm{H} 32$ were considered as the best ones regarding to the yield and lowest natural pest infestation, Meanwhile, the $\mathrm{H} 19$ L96 genotype surpassed the yield of Giza35 (check). Razmjou et al. (2009) indicated significant differences among mite population growth parameters on soybean cultivars, where T. urticae displayed lower population growth on Zane cultivar than on other cultivars including Hob 9 Will and L17. El-Sanady et al. (2007) revealed high significant differences between soybean varieties in their relative susceptibility to T. urtica infestation where Crawford variety was the most susceptible to T. urticae; while Giza 35was the highest tolerant to it; results which coincide with our findings.

\section{Relation be tween his tological characters of leaves and $T$. urticae infestation:}

Negative significant correlation coefficient values were found between the abundance of T. urticae and the thickness of the upper and lower epidermis, and palisade tissues $(-0.76,-0.8$ and -0.79$)$. On the other hand, a significantly positive correlation with the spongy tissue $(\mathrm{r}=0.89)$ was observed (Table 2, Figs. $1 \& 2$ ). This proved that, leaf thickness is an important factor influencing mite infestation.

The highest population density of the mite was significantly recorded on H15L27 genotype in comparison with the other soybean genotypes, due to the thinness of upper and lower epidermis, and palisade tissues besides the thickness of spongy tissue of the leaves of this genotype. Similar trends were reported by Hanafy (2004) for cucumber varieties and the abundance of $T$. urticae motile stages. The more thickness of the cuticle epidermis especially that of the lower surface could be considered as a physical tolerance factor against mechanism of spider mite, (El-Sanady et al., 2008). Shakoor et al. (2010) reported that leaf thickness is very important factor affecting the reproduction and development of mite populations. Abo-Zaid (2013) indicated significant differences between five tested cucumber cultivars in their relative susceptibility to $T$. urticae infestation in two seasons, and grouped them into highest and lowest infested groups. All the above mentioned data support the results of the present investigation. In 
Table (1): Total number of motile stages and eggs of T. urticale during the two seasons 2012 and 2013

\begin{tabular}{ccccc}
\hline \multirow{2}{*}{ Genotypes } & \multicolumn{3}{c}{2012} & \multicolumn{2}{c}{2013} \\
\cline { 2 - 5 } & Motile stages & F.ggs & Motile stages & Lggs \\
\hline H19L96 & $2416 \pm 5.7^{\mathrm{f}}$ & $1533.3 \pm 1.2^{\mathrm{g}}$ & $1573.33 \pm 15.5^{\mathrm{f}}$ & $1309 \pm 1.15^{\mathrm{f}}$ \\
\hline Giza 111 & $2738.7 \pm 5.2^{\text {ef }}$ & $1709 \pm 4.6^{\mathrm{fig}}$ & $1588 \pm 3.46^{\mathrm{ef}}$ & $1490 \pm 4.6^{\mathrm{e}}$ \\
\hline L117 & $2853.6 \pm 1.2^{\mathrm{def}}$ & $1795 \pm 3.5^{\mathrm{f}}$ & $1618 \pm 5.48^{\mathrm{ef}}$ & $1541 \pm 3.46^{\mathrm{c}}$ \\
\hline H32 & $3197.7 \pm 1.7^{\text {cdef }}$ & $2163.3 \pm 6.4^{\mathrm{e}}$ & $1672.3 \pm 17.47^{\mathrm{ef}}$ & $1591.3 \pm 6.35^{\mathrm{de}}$ \\
\hline H4L24 & $3197.3 \pm 5.19^{\text {cdef }}$ & $2209 \mathrm{~d} \pm 5.2^{\mathrm{e}}$ & $1750 \pm 5.77^{\mathrm{e}}$ & $1656 \pm 5.19^{\mathrm{cd}}$ \\
\hline Giza 35 & $3785.7 \pm 3.4^{\text {bcde }}$ & $2359 \pm 5.8^{\mathrm{cde}}$ & $1947.67 \pm 10.9^{\mathrm{d}}$ & $1666.7 \pm 5.77^{\mathrm{cd}}$ \\
\hline Crawford & $3836 \pm 1.2^{\text {bcde }}$ & $2429 \pm 1.2^{\text {cd }}$ & $2194.6 \pm 8.6^{\mathrm{c}}$ & $1752 \pm 1.15^{\mathrm{c}}$ \\
\hline H30 & $3879 \pm 1.2^{\mathrm{abcd}}$ & $2565.3 \pm 4.6^{\mathrm{c}}$ & $2202.6 \pm 4.6^{\mathrm{c}}$ & $1867 \pm 4.6^{\mathrm{b}}$ \\
\hline L127 & $4184.3 \pm 3.5^{\mathrm{abc}}$ & $2963 \pm 1.7^{\mathrm{b}}$ & $2310.67 \pm 16.8^{\mathrm{c}}$ & $1873 \pm 1.7^{\mathrm{b}}$ \\
\hline H1L1 & $4567 \pm 4.6^{\mathrm{ab}}$ & $3462.6 \pm 3.5^{\mathrm{a}}$ & $2600.67 \pm 8.1^{\mathrm{b}}$ & $2193 \pm 3.5^{\mathrm{a}}$ \\
\hline H15L27 & $4980.3 \pm 3.5^{\mathrm{a}}$ & $3670 \pm 1.7^{\mathrm{a}}$ & $2832 \pm 7.2^{\mathrm{a}}$ & $2248 \pm 1.7^{\mathrm{a}}$ \\
\hline
\end{tabular}

Fach value is a mean $\pm \mathrm{SD} ; \mathrm{n}=20$, Means followed by the same superscript (s) are not significantly differed by the least significant difference $(\mathrm{p}<0.05)$ (Duncan, 1955).

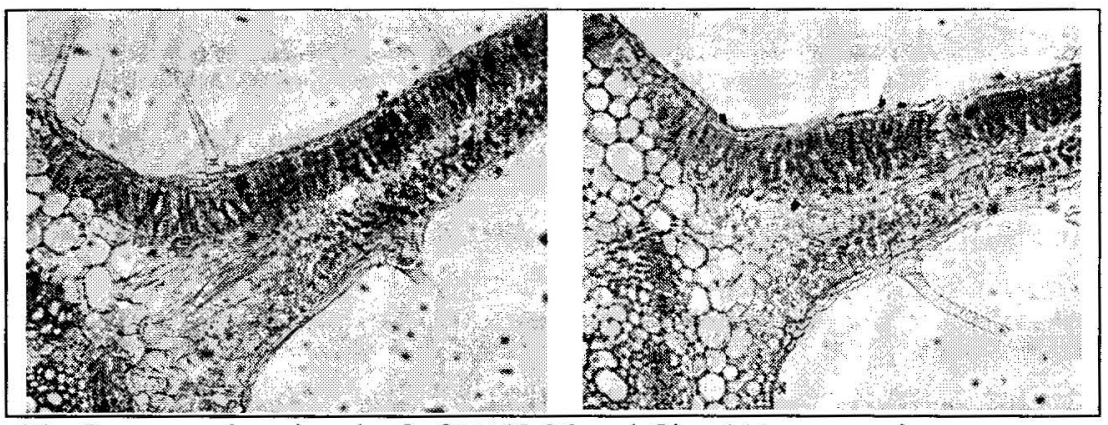

Fig. (1): Cross sections in a leaf of H19L96 and Giza 111 as a resistance genotypes.

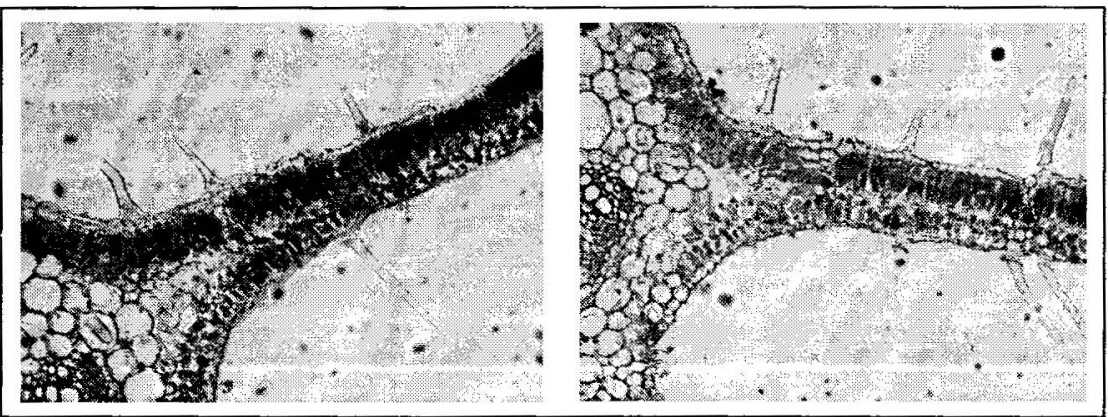

Fig. (2): Cross sections in a leaf of H15L27 and H1L1 as sensitive genotypes.

Table (2): Histological characters of leaves and their correlation coefficient with the population density of motile stages and eggs of T.urticae during the two seasons 2012 and 2013.

\begin{tabular}{ccccc}
\hline \multirow{2}{*}{ Soybean Genotypes } & \multicolumn{4}{c}{ Mean diameters of leaf layers $(\mu)$} \\
\cline { 2 - 5 } & Upper epidermis & Palisade tissue & Spongy tissue & Lower epidermis \\
\hline H19L96 & $17.67 \pm 1.2^{\mathrm{a}}$ & $90.53 \pm 2.72^{\mathrm{a}}$ & $51.86 \pm 1.84^{\mathrm{ef}}$ & $14.28 \pm 0.96^{\mathrm{a}}$ \\
\hline Giza 111 & $16.21 \pm 0.43^{\mathrm{ab}}$ & $84.75 \pm 2.44^{\mathrm{ab}}$ & $64.45 \pm 1.7^{\mathrm{fb}}$ & $13.87 \pm 0.96^{\mathrm{a}}$ \\
\hline L117 & $16.1 \pm 0.46^{\mathrm{ab}}$ & $81.95 \pm 1.38^{\mathrm{b}}$ & $67 \pm 2.96^{\mathrm{b}}$ & $13.38 \pm 0.5^{\mathrm{ab}}$ \\
\hline H32 & $15.9 \pm 1.37^{\mathrm{abc}}$ & $73.34 \pm 1.78 \mathrm{c}$ & $73.4 \pm 1^{\mathrm{ef}}$ & $12.97 \pm 0.8^{\mathrm{abc}}$ \\
\hline H4L24 & $14.19 \pm 0.59^{\mathrm{bcd}}$ & $70.75 \pm 1.53^{\mathrm{cd}}$ & $76.7 \pm 5.45^{\mathrm{de}}$ & $11.82 \pm 0.46^{\mathrm{bcd}}$ \\
\hline Giza 35 & $13.93 \pm 1.38^{\mathrm{bcd}}$ & $66.35 \pm 2.28^{\mathrm{de}}$ & $79.77 \pm 2.17^{\mathrm{de}}$ & $11.24 \pm 0.69^{\mathrm{cd}}$ \\
\hline Crawford & $13.49 \pm 0.73^{\mathrm{cd}}$ & $64.3 \pm 3.51^{\mathrm{de}}$ & $83.34 \pm 3.17^{\mathrm{cd}}$ & $11.1 \pm 0.36^{\mathrm{d}}$ \\
\hline H30 & $12.93 \pm 0.84^{\mathrm{d}}$ & $61.8 \pm 1.38^{\mathrm{ef}}$ & $89 \pm 0.86^{\mathrm{b}}$ & $10.89 \pm 0.6^{\mathrm{e}}$ \\
\hline L127 & $9.95 \pm 0.55^{\mathrm{e}}$ & $60.87 \pm 2.31^{\mathrm{ef}}$ & $91.45 \pm 2.16^{\mathrm{b}}$ & $8.59 \pm 0.91^{\mathrm{e}}$ \\
\hline H1L1 & $9.46 \pm 0.44^{\mathrm{e}}$ & $56.43 \pm 2.51^{\mathrm{f}}$ & $104.7 \pm 2.47^{\mathrm{a}}$ & $7.9 \pm 0.76^{\mathrm{e}}$ \\
\hline H15L27 & $9.08 \pm 0.63^{\mathrm{e}}$ & $55.56 \pm 2.48^{\mathrm{f}}$ & $107.9 \pm 0.9^{\mathrm{a}}$ & $7.68 \pm 0.52^{\mathrm{e}}$ \\
\hline Motile stages & $-0.766^{* * *}$ & $-0.79^{* * *}$ & $0.89^{* * *}$ & $-0.8^{* * *}$ \\
\hline Eggs & $-0.3089^{*}$ & $-0.29^{*}$ & $0.4^{* * *}$ & $-0.3024^{*}$ \\
\hline
\end{tabular}

Each value is a mean $\pm S D ; n=20, \quad$ Means followed by the same superscript (s) are not significantly differed by the least significant Difference $(\mathrm{p}<0.05)$ (Duncan, 1955). 
general, genotypes characterized by thicker layers of the upper and lower epidermis, and palisade tissues were less susceptible to spider mite infestation and subsequently, infested by fewer population and vice versa.

Relation between phytochemical constituents of leaves from different soybean ge notypes and T.urticae infestation:

Data indicated a positive significant correlation between mite infestation levels and leaves nitrogen and potassium contents $(0.7788$ and 0.7513$)$ and $(0.556$ and 0.2586$)$ for motile stages and eggs population of T.urticae respectively, while negative correlation was found with phosphorous $(-0.69$ and 0.295), for the two seasons 2012 and 2013, respectively (Table 3 ).

The lowest population density of total life stages of T. urticae was obtained for H19L96 genotype as shown in Table 3. The decrease of phosphorus and nitrogen and the increase of potassium contents may be an important reason for unsuitability and decrease of the population density of the mite. Several studies (e.g., Yokama, 1978; Taha et al., 1993; Taha and Raies, 1996; Gamieh and El-Basuony, 2001 and El-Sanady et al., 2007) found significant negative correlation between leafe contents of potassium and positive correlation between phosphorus and nitrogen with respect to population densities of T.urticae.

\section{Relation between population of each of Phytoseiulus persimilis and Scolothrips sexmaculatus and that of T. urticae on soybean genotypes: \\ Total population of the predatory mite $P$. persimilis and the thrips $S$. sexmaculatus are shown}

Table (3): Phytochemical characters of leaves and their correlation coefficient with the population density of different stages and eggs of T.urticae during the two seasons 2012 and 2013

\begin{tabular}{cccc}
\hline Soybean Genotypes & Nitrogen $\%$ & Phosphorous\% & Potassium\% \\
\hline H19L96 & $0.28 \pm 0.02^{\mathrm{h}}$ & $0.72 \pm 0.01^{\mathrm{a}}$ & $0.95 \pm 0.9^{\mathrm{e}}$ \\
\hline Giza 111 & $0.32 \pm 0.28^{\mathrm{g}}$ & $0.29 \pm 0.01^{\mathrm{b}}$ & $0.98 \pm 0.01^{\mathrm{de}}$ \\
\hline L117 & $0.35 \pm 0.1^{\mathrm{f}}$ & $0.25 \pm 0.02^{\mathrm{bc}}$ & $1.01 \pm 0.04^{\mathrm{de}}$ \\
\hline H32 & $0.38 \pm 0.04^{\mathrm{ef}}$ & $0.22 \pm 0.01^{\mathrm{cd}}$ & $1.06 \pm 0.1^{\mathrm{cde}}$ \\
\hline H4L24 & $0.4 \pm 0.3^{\mathrm{e}}$ & $0.22 \pm 0.02^{\text {cd }}$ & $1.12 \pm 0.07^{\mathrm{bcde}}$ \\
\hline Giza 35 & $0.41 \pm 0.3^{\mathrm{c}}$ & $0.18 \pm 0.01^{\mathrm{de}}$ & $1.47 \pm 0.3^{\mathrm{abcde}}$ \\
\hline Crawford & $0.46 \pm 0.1^{\mathrm{d}}$ & $0.16 \pm 0.02^{\mathrm{ef}}$ & $1.25 \pm 0.02^{\mathrm{abcd}}$ \\
\hline H30 & $0.14 \pm 0.01^{\mathrm{ef}}$ & $1.33 \pm 0.02^{\mathrm{abc}}$ \\
\hline L127 & $0.47 \pm 0.08^{\mathrm{d}}$ & $0.12 \pm 0.01^{\mathrm{f}}$ & $1.37 \pm 0.02^{\mathrm{ab}}$ \\
\hline HLL1 & $0.53 \pm 0.02^{\mathrm{c}}$ & $0.06 \pm 0.02^{\mathrm{g}}$ & $1.47 \pm 0.02^{\mathrm{a}}$ \\
\hline H15L27 & $0.57 \pm 0.04^{\mathrm{b}}$ & $1.52 \pm 0.01^{\mathrm{a}}$ \\
\hline Motile stages & $0.63 \pm 0.08^{\mathrm{a}}$ & $0.02^{\mathrm{g}}$ & \\
\hline Eggs & Correlation Coefficient values(r) & 0.2586 \\
\hline
\end{tabular}

Table (4): Density of Predators and their correlation coefficient with the population density of motile stages and eggs of T. urticae during the two seasons 2012 and 2013

\begin{tabular}{|c|c|c|c|c|}
\hline \multirow[t]{2}{*}{ Genotypes } & \multicolumn{2}{|c|}{2012} & \multicolumn{2}{|c|}{2013} \\
\hline & P. persimilis & S. sexmaculatus & P. persimilis & S. sexmaculatus \\
\hline H19L96 & $82.7 \pm 5.2^{8}$ & $51.3 \pm 5.2^{8}$ & $209 \pm 5.19^{h}$ & $48+1.7^{d}$ \\
\hline Giza 111 & $104 \pm 9.2^{\text {fg }}$ & $70 \pm 4^{\mathrm{f}}$ & $316+9.2^{\mathrm{g}}$ & $48+4.1^{\mathrm{d}}$ \\
\hline $\mathrm{L} 117$ & $112 \pm 4 \mathrm{~g}$ & $83 \pm 1.7^{e}$ & $402.7 \pm 4.1^{\mathrm{e}}$ & $44 \pm 5.2^{d}$ \\
\hline $\mathrm{H} 32$ & $143 \pm 6.9^{\text {ef }}$ & $107 \pm 1.7^{\mathrm{d}}$ & $403 \pm 1.7^{\mathrm{e}}$ & $77 \pm 2.3^{c}$ \\
\hline H4L24 & $157.3 \pm 4.6^{\mathrm{e}}$ & $145 \pm 2.3^{c}$ & $372 \pm 6.9^{f}$ & $55 \pm 4.1^{\mathrm{d}}$ \\
\hline Giza 35 & $184.7 \pm 3.5^{\text {de }}$ & $142 \pm 4^{c}$ & $428+4.6^{\mathrm{d}}$ & $53 \pm 2.3^{d}$ \\
\hline Crawford & $180 \pm 1.7^{\mathrm{de}}$ & $139 \pm 2.3^{\mathrm{c}}$ & $533 \pm 1.7^{c}$ & $75 \pm 2.8^{c}$ \\
\hline $\mathrm{H} 30$ & $202.66 \pm 1.7^{\mathrm{cd}}$ & $155 \pm 3.7^{c}$ & $526 \pm 3.4^{c}$ & $70+2.8^{c}$ \\
\hline L127 & $234 \pm 8.7^{b c}$ & $145 \pm 2.8^{c}$ & $535 \pm 8.6^{\mathrm{c}}$ & $81 \pm 3.4^{c}$ \\
\hline HIL1 & $247 \pm 4.6^{b}$ & $184 \pm 2.3^{b}$ & $688.3 \pm 4.6^{\mathrm{b}}$ & $94 \pm 2.3^{b}$ \\
\hline H15L27 & $330 \pm 15.2^{\mathrm{a}}$ & $270 \pm 4^{\mathrm{a}}$ & $765 \pm 15.3^{\mathrm{a}}$ & $147 \pm 4^{\mathrm{a}}$ \\
\hline \multicolumn{5}{|c|}{ Correlation Coefficient values(r) } \\
\hline P. persimilis & $-0.535^{* *}$ & $-0.807^{* * *}$ & $-0.9131^{* * *}$ & $-0.3884^{*}$ \\
\hline S. sexmaculatus & $-0.5805^{* * *}$ & $-0.865^{* * *}$ & $-0.7455^{* * *}$ & $-0.7455^{* * *}$ \\
\hline
\end{tabular}

Each value is a mean $\pm S D ; n=20, \quad$ Means followed by the same superscript (s) do not significantly differ by the least sigrificant difference $(\mathrm{p}<0.05)$ (Duncan, 1955). 
in Table 4. P. persimilis populations on the most susceptible genotype (H15L27) was 330 and 270 significantly greater than the most resistant genotype (H19L96) 82.7 and 51.3 at the two successive seasons, respectively, while those of the predatory thrips S. sexmaculatus populations were 765 and 147 on (H15L27) and 209 and 44 on (H19L96).

Total predator populations were significantly greater on sensitive leaflets as shown in Table 4. The reduction in its populations on resistant genotypes was due to the absence of sufficient prey on resistant leaflets resulting in emigration and cannibalism among the predators; this agreed with findings of Sabelis (1981). According to Wheatleyl and Boethel (1992), predator populations could achieve control of spider mites faster on resistant than on susceptible ones, or both. It's interestingly to mention that, the number of preys consumed daily by the first and second instars larvae of Scolothrips longicomis was estimated to be 6.8 and 4.6 of motile stages of $T$. urticae, respectively, Pakyari, et al. (2009). In comparison with other spider mite predators, the daily consumption of $T$. urticae eggs by $S$. longicornis female (24 eggs per day at $26^{\circ} \mathrm{C}$ ) was higher than reported for the phytoseiid females Phytoseiulus persimilis Athias-Henriot ( 14.9 eggs per day at $25^{\circ} \mathrm{C}$ ) Friese and Gilstrap (1985) and Amblyseius californicus (McGregor) (13.4 eggs per day at $25^{\circ} \mathrm{C}$ ) Gotoh et al. (2004a). (Pakyari and Enkegaard, 2011). These differences can be attributed to variations in their genetic makeup. It can also be of significant importance in a variety introduction programme as a source of resistance for further improvement of soybean genotypes.

Through the methods of hybridization and genetic recombination, pest resistant traits from resistant sources can be transferred to the agronomic acceptable genotypes. The obtained data can be utilized as a baseline for IPM programme for achieving better control against $T$. urticae on soybean.

Thus, in Integrated Pest Management (IPM) programs, choice of resistance genotypes is one of the major components in this strategy; by other words, the use of resistant genotypes in association with the use of natural enemies could promote better control of the target pests. This research demonstrated that the tested soybean genotypes had significant effects on the population density of $T$. urticae. The highest population density of the pest was seen on H15L27 and the lowest was on H19L96 genotype; while Crawford had an intermediate values. In this respect, our assessment was based on efficiency of natural enemies, histological and phytochemical characters of leaves of the different soybean genotypes. Hence, the use of resistant genotypes in association with the use of natural enemies or pesticides could promote better control of pest.

\section{REFERENCES}

Abou-Zaid, A. M. M. 2013. The relation between the anatomical characters of five different cucumber cultivars leaves and Tetranychus urticae koch (Acarina: Actenididea: Tetranychidae) infestation under filed conditions. Egypt. Acad. J. Biol. Sci., $6(1): 27-34$.

Alakhdar, H. H.; Ghareeb, Z. E., Rabie, E. M. 2015. Evaluation some genotypes of soybeans yield under pest infestation. Inter. J. of Sci. Res. In Agric. Sci., 2: 07-017.

Baker, W. H. and Thompson, T. L. 1992. Determination of total nitrogen in plant samples by Kjeldahl. In: Plant analysis reference procedures for the Southern region of the United State, Southern cooperative series Bulletin 368, ed. C. O. Plank, pp. 13-16. Athens: The Georgia Agricul. Exp. Stat., Univ. of Georgia.

De Mejia, E. G.; Bradford, T. and Hasler, C. 2003. The anticarcinogenic potential of soybean. lectin and lunasin. Nutrition Reviews., 61: 239-246.

Donohue, S. J. and Aho, D.W. 1992. Determination of $\mathrm{P}, \mathrm{K}, \mathrm{Ca}, \mathrm{Mg}, \mathrm{Mn}, \mathrm{Fe}, \mathrm{Al}, \mathrm{B}, \mathrm{Cu}$ and $\mathrm{Zn}$ in plant tissue by inductively coupled plasma (ICP) emission spectroscopy. In 'Plant analysis reference procedures for the Southern United States'. (Ed COPlank) pp. 34-37. Southern Coop. Ser. Bull. 368. Univ. of Georgia, Athens.

Duncan, D. 1955. Multiple ranges and multiple "F" test. Biometrics, 11: 1-42.

El-Sanady, M. A.; Soliman, S. M. and Younis, A.Y. 2008. Field and laboratory studies to evaluation five soybean varieties for their relative susceptibility to the two spotted spider mite Tetranychus urticae Koch infestation (Acarina: Tetranychidae: Actenidida). Egypt. J. Agric. Res., 86(1): 77-88.

Friese, D. D. and Gilstrap, F. E. 1985. Prey requirements and developmental times of three phytoseiid species predacious on spider mites. Southwest Entomol., 10: 83-88.

Gamieh, G. N. and El-Basuony, A. A. 2001. Population Densities of piercing sucking pests in soybean field as influenced by varieties, predators and leaf physical and chemical properties. J. Agric. Sci. Mans. Univ., 26(2): 1089-1099.

Georghiou, G. P.1990. Overview of insecticide resistance. In: Green, M. B.; Le Baron, H.M. and Moberg, W. K., Eds. Managing Resistance to Agrochemicals. Am. Chem. Soc. pp. 18-41.

Gotoh, T.; Nozawa, M. and Yamaguchi, K. 2004. Prey consumption and functional response of three a-carophagous species to egg of the twos potted 
spider mite in the laboratory. App. Entomol. Zool., 39: 97-105.

Hanafy, A. R. I. 2004. Studies on the most important cucumber pests in the open field and suitable control programs. Ph.D. Thesis. Fac. of Agric., Moshtohor, Zagazig Univ. 279 pp.

Jackson, G. 1976. Crystal violet and erythrosine in plant anatomy. Stain Technique, 1: 33-34.

Jyoti, J. L.; Shelton, A.M. and Earle, E. D. 2001. Identifying sources and mechanisms of resistance in crucifers for control of cabbage maggot (Diptera: Anthomyiidae). J. Econ. Entomol., 94: 942-949.

Kou, K. P.; Robert, S. S. and Richard, C. 1972. Leaf characteristics of spider mite resistant and susceptible cultivars of Pelarogonimx hotium. Entomol. News, 83:181-197.

Luczynski, A.; Isman, M. B.; Raworth, D. A. and Chan, C. K. 1990. Chemical and morphological factors of resistance against the two-spotted spider mite in beach strawberry. J. Econ. Entomol., 83(2): 564-569.

Martinez-Ferrer, M.T.; Jacas, J. A.; Piolles-Moles, J. L. and Aucejo-Romero, S. 2006. Approaches for sampling the two spotted spider mite (Acari: Tetranychidae) on clementines in Spain. J. Econ. Entomol., 99: 1490-1499.

Massoud, A. H.; Derbalah, A. S.; El-Shshtaway, H.F. and Sleem, M. 2014. Efficacy, persistence and removal of chlorpyrifos-methyl after application against cotton leaf worm in soybean. J. Mater. Environ. Sci., 5(5): 1398-1405

Modarres, N. S. S. 2012. Resistance to Tetranychus urticae Koch (Acari: etranychidae) in Phaseolus vulgaris L. Middle-East J. Sci. Res., 11 (6): 690701.

Mohamed, I. I. and AbdelHafez, M. A. 1981. Susceptibility of some different varaities of soybeans to infestation with spider mites. Agric. Res. Rev., 59(1): 35-38.

Nahar, N.; Islam, W. and Hague, M. M. 2005. Predation of three predators on two-spotted spider mite, Tetranychus urticae Koch (Acari: Tetranychidae). J. Life Earth Sci., 1: 1-4.

Nguyen, T. D.; Lee, M. H. and Lee, G. H. 2010. Rapid determination of 95 pesticides in soybean oil using liquid-liquid extraction followed by centrifugation, freezing and dispersive solid phase extraction as cleanup steps and gas chromatography with mass spectrometric detection. Microchem. J., 95: 113-119.

Pakyari, H. and Enkegaard, A. 2012. Effect of different temperatures on consumption of two spotted mite, Tetranychus urticae eggs by the predatory thrips, Scolothrips longicornis. J. Ins. Sci., 12: 9-18.

Pakyari, H.; Fathipour, Y.; Reapanah, M. and Kamali,
K. 2009. Temperature dependent functional response of Scolo thrips longicomis (Thysanoptera: Thripidae) preying on Tetranychus urticae J. Asia Pasific Entomol., 12(1): 23-26.

Razmjou J.; Tavakkoli, H. and Fallahi, A. 2009. Effect of soybean cultivar on life history parameters of Tetranychus urticae Koch (Acari: Tetranychidae). J. Pest Sci., 82: 89-94.

Ruzin, S. E. 1999. Plant microtechnique and microscopy. Oxford University Press. Oxford, New York, $322 \mathrm{pp}$.

Sabelis, M. W.1981. Biological control of twospotted spider mites using phytoseiid predators. Part I. Ctr Agric. Publ. Doc., Wageningen, The Netherlands.

Saber, S. A. and Momen, F. M. 2005. Influence of plant leaf texture on the development, reproduction and life table parameters of the predacious mite Cydnoseius zaheri (Phytoseiidae: Acarina). Acta Phytopathol. Entomol.Hung., 40: 177-184.

Sawires, Z. R.; Taha, H. A. and Abdalla, S. T. 1990. Biological and ecological studies on Tetranychus arabicus and relative susceptibility of seventeen soybean genotypes to infestation. Agric. Res. Rev., 68(1): 17-24.

Shakoor, A.; Sabr, M. A.; Afzal, M. and Bashir, M. H. 2010. Role of plant morphological characters towards resistance of some cultivars of tomato against phytophagous mites (acari) under green house conditions. Pak. j. life soc. Sci., 8 (2): 131-136.

Taha, H. A. and El-Raies, S. A. A. 1996. Influence of water salinity irrigation on spider mite infestation and cotton leaves contents. Proc. Acarol. Cong. IX Ohaio-M.S.A., (1): 257-260.

Taha, H. A.; Sedrak, R. A.; Abdalla, S. T. and Sharaf, A. E. 1993. Evaluation of some soybean genotypes for their resistance to spider mite infestation. Egypt. J. Biol. Pest Cont., 3(1): 41-46.

Turhan, N.; Tunc, A.; Belli, A.; Kismir, A. and Kisakurek, N. 1983. Studies on the determination of the insect and mite fauna of soybean (Glycine $\max L$.) in the Cuckurova district, Bitki-Koruma Bulteni, 23(3): 148169.

Wheatleyl, J. A. C. and Boethel, D. J. 1992. Populations of Phytoseiulus persimilis(Acari: Phytoseiidae) and Its host, Tetranychus urticae (Acari: Tetranychidae) on resistant and susceptible soybean cultivars. J. Econ. Entomol., 85 (3): 731-738.

Yokama,V. Y. 1978. Relation of seasonal changes in extra floral nectar and foliar protein and arthropod population in cotton. Environ. Entomol., 7(6): 799-802. 